УДК 37.015.311:172.15

DOI: 10.37026/2520-6427-2020-101-1-118-120
Лариса ПАНІНА,

кандидат історичних наук,

дочент кафедри суспільно-гуманітарної освіти

Рівненського ОІППО

\title{
НАЦІОНАЛЬНО-ПАТРІОТИЧНЕ ВИХОВАННЯ УЧНІВСЬКОЇ МОЛОДІ В УМОВАХ НОВОЇ УКРАЇНСЬКОЇ ШКОЛИ
}

У статті окреслено основні підходи до розуміння начіонально-патріотичного виховання учнівської молоді в умовах Нової української школи як системи заходів, спрямованих на формування «нового» громадянина України, що діє на основі начіональних та європейських иінностей.

Ключові слова: національно-патріотичне виховання, громадянин, громадянське суспільство, громадянське виховання, громадянський патріотизм, нація, Батьківщина, національні традииії, національна свідомість

В статье рассматриваются основные подходы $\kappa$ пониманию национально-патриотического воспитания ученической молодёжи как системы мероприятий, направленных на формирование «нового» гражданина Украины, что действует на основе национальных и европейских ценностей.

Ключевые слова: начионально-патриотическое воспитание, гражданин, гражданское общество, гражданское воспитание, гражданский патриотизм, нация, Родина, наџиональные традиции, наииональное сознание.

In the article approaches to understanding the national-patriotic upbringing of student youth in the context of the New Ukrainian School as a system of measures aimed at forming a «new» citizen of Ukraine, acting on the basis of national and European values are outlined.

The strategic goal of our country's social development is the formation of civil society and the building of a legal democratic state. The main guarantee for the formation of a democratic state is, first and foremost, the upbringing of a clear civic position with a high level of national-patriotic, political-legal, moral, economic and social activity in the younger generation. In this context, there is a need for civic education, which aims to help the younger generation overcome political apathy, develop patriotic qualities, teach tolerance in any conflict situations, solve various social problems. The basis for the creation of a democratic state should be a citizen with his active citizenship.

The problems of national-patriotic upbringing of student youth were addressed: G. Vashchenko, O. Dukhnovych, A. Makarenko, V. Sukhomlinsky, O. Ogienko, S. Rusova, G. Skovoroda, K. Ushinskiy and others. In their works, prominent teachers and scholars identified the problems of development of national-patriotic feelings as relevant to their time as part of the national education system, put forward the idea of educating a «conscious» citizen, a patriot of their homeland.
Transformation of education is accompanied by significant updating of pedagogical theory and practice, there is a change of educational paradigm, other content, approaches, pedagogical mentality are offered, forms and methods of teaching are improved. The Ministry of Education and Science of Ukraine introduced educational reform, which is being implemented at the New Ukrainian School. Ideas of civic education have always been relevant to the pedagogical elite of Ukraine.

The purpose of patriotic education is the education of a conscious citizen, a patriot, the acquisition of social experience by young people, a high culture of interethnic relations, the formation of young people's needs and ability to live in a society, spirituality and physical excellence, moral, artistic and aesthetic culture.

Key words: national-patriotic education, citizen, civil society, civic education, civic patriotism, nation, homeland, national traditions, national consciousness.

Постановка проблеми. Формування громадянського суспільства та побудова демократичної правової держави $\epsilon$ стратегічною метою соціального розвитку України. Відродження й оновлення громадянської свідомості, збереження власної історії, територіальної цілісності, розвиток культури - це ті чинники, які сьогодні творять майбутнє нашої держави. Дотримання цих засад на основі національно-патріотичного виховання є особливо вагомим поштовхом для досягнень України та українців на світовій арені.

Основою створення демократичної держави має стати громадянин із його активною громадянською позицією. Патріотизм - одна 3 найважливіших рис всебічно розвиненої особистості, адже кожна людина, а поготів соціальна група, проявляє свої специфічні інтереси і цим визначається іiі розуміння патріотизму. Під патріотичним вихованням розуміємо поступове і неухильне формування в учнів любові до своєї Батьківщини.

У школах патріотичне виховання спрямовується на залучення учнів до глибинних пластів національної культури і духовності, формування в них національних світоглядних позицій, ідей, поглядів і переконань на основі цінностей вітчизняної та світової культури. Воно здійснюється на всіх етапах навчання в школі та забезпечує всебічний розвиток, гармонійність і цілісність особистості, розвиток іiі здібностей та обдарованість, збагачення на цій основі інтелектуального потенціалу народу, його духовності і культури, виховання громадянина України, здатного до самостійного мислення, суспільного вибору і діяльності, спрямованої на процвітання держави. 
При цьому дух нації $є$ основою національної свідомості і виховання, тому він має бути присутнім у всьому, що оточує дитину, та перебувати в єдності із зовнішньою національною атрибутикою.

Аналіз наукових досліджень і публікацій. До проблем національно-патріотичного виховання учнівської молоді зверталися В. Антонович, М. Драгоманов, Б. Грінченко, Г. Ващенко, О. Духнович, А. Макаренко, В. Сухомлинський, О. Огієнко, С. Русова, Г. Сковорода, К. Ушинський та ін. У своїх працях видатні педагоги та науковці визначали актуальні для свого часу проблеми розвитку національно-патріотичних почуттів як частини національної системи виховання, висували ідею виховання «свідомого» громадянина, патріота своєї Батьківщини [10].

На основі традицій та звичаїв українського народу національно-патріотичне виховання вивчали М. Грушевський, О. Гевко, О. Вишневський, М. Стельмах, М. Щербань та ін. [2].

Так, М. Грушевський у своїй книзі «На порозі нової України» пише про ідеал розбудови Української незалежної держави [1]. Без сумніву, в цьому політичному заповіті $є$ багато того, над чим варто замислитися й нашому сучаснику. Видатний учений наголошував, що виховання в громадян почуття обов'язку перед Батьківщиною - це найвищий стимул громадянського життя, який має об'єднати весь народ в одному пориві, долаючи політичні, партійні відмінності й розбіжності там, де починаються основні інтереси держави.

У працях Я. Чепіги, В. Гонського, М. Качура, О. Коркішко, І. Мартинюка, В. Паплужного, Ю. Римаренко, О. Сухомлинської описується взаємодія, а також функціонування зв'язків із національним, патріотичним, громадянським вихованням тощо.

На противагу цьому, сучасні вчені та педагоги (П. Коненко, В. Андрущенко, В. Гуменко, М. Дробноход, А. Погрібний та ін.) вважають, що, «...незважаючи на особливу актуальність завдань патріотичного виховання, сучасна наука і педагогіка не виховали людини, пріоритетними принципами якої були б принципи патріотизму...» [3].

Мета статті - проаналізувати сутність національно-патріотичного виховання учнівської молоді в умовах нової української школи.

Виклад основного матеріалу. Трансформація освіти супроводжується суттєвим оновленням педагогічної теорії й практики, удосконалюються форми й методи навчання, педагогічний менталітет, а також пропонується інший зміст та підходи. МОН України запровадило освітню реформу, яка реалізується в Новій українській школі. Сьогодні національно-патріотичне виховання учнівської молоді набуває особливої актуальності, адже воно зумовлене формуванням почуття любові та відданості Батьківщині, служінню своєму народові, розумінню та співпереживанню його історії й культури, прагненню утвердження у світі як високорозвиненої, інноваційної, успішної, конкурентоздатної нації. Головним чинником створення незалежної, демократичної держави має стати людина $з$ активною громадянською позицією.

Під національно-патріотичним вихованням розуміємо поступове й неухильне формування в молодого покоління любові до своєї Батьківщини, народу, родини, школи, колективу, класу. Однією із найвагоміших рис усебічно розвиненої, високоосвіченої, толерантної особистості є патріотизм.
Розвиток альтернативних підходів до розуміння національно-патріотичного виховання учнівської молоді та духовно-етичні цінності нації є ідеологічною стратегією патріотичного виховання в сучасній новій українській школі.

Варто зауважити, що формування національної самосвідомості майбутніх громадян без оволодіння рідною мовою, без реформи національної системи освіти, культури й моралі неможливе. Лише тоді, коли українська національна ідея та моральна реформа «підуть» попереду, запрацюють і всі інші, зокрема й політична та економічна. Краща форма боротьби 3 агресивною бездуховністю - протиставити їй духовність і культуру нації, народу, культуру людини, культуру праці та поведінки [2].

Ключова мета НУШ - виховати інноватора та громадянина, який вміє приймати відповідальні рішення й дотримується прав і свобод людини. При цьому основною метою системи національної освіти $\epsilon$ створення умов для особистісного розвитку та творчої самореалізації кожного громадянина України, що зможе навчатися протягом усього життя, створювати й розвивати цінності громадянського суспільства на підставі виявлення його задатків, здібностей, обдарувань і талантів. Тому важливо розвивати інтелектуальний, творчий, життєвий потенціал учнів, навчати їх критично мислити, володіти собою, спілкуватися з іншими людьми, швидко орієнтуватися в складних життєвих ситуаціях та знаходити правильні рішення. Крім того, розвиток та виховання особистості неможливі без творчого, професійного, компетентного вчителя.

Учитель в умовах НУШ має змогу реалізувати всі компоненти життєвотворчого потенціалу, шляхи реалізації якого полягають у творчому підході до організації кожного уроку, проведення виховних та позакласних заходів, роботи гуртків, партнерської взаємодії з батьками, вчителями та адміністрацією [7].

Отже, щоб забезпечити ефективність національно-патріотичного виховання школярів, педагог має володіти інноваційними методами, прийомами, засобами та формами його здійснення. Зокрема, Н. Мойсеюк виокремлює такі групи методів патріотичного виховання:

I група - методи усвідомлення цінностей патріотичного виховання (любов до Батьківщини, служіння iï інтересам, здоровий спосіб життя, піклування про природні багатства рідної землі). В основу цих методів покладено слово - могутню зброю в умілих руках педагога;

II група - методи організації діяльності та формування досвіду суспільної поведінки (тренування, привчання, доручення, педагогічна вимога, ситуація вільного вибору, ігровий метод);

III груnа - методи стимулювання поведінки і діяльності. До них відносяться методи заохочення, змагання та дуже обережно - покарання;

IV груnа - методи педагогічної підтримки, а саме: взаємна довіра, спільне проведення виховних заходів, ігор, діагностика індивідуального розвитку, вихованості тощо. Важливе значення у цьому відводиться створенню ситуації успіху та умов для самореалізації особистості [6].

До сучасних методів належить метод проєктів із використанням IКТ. Його впровадження грунтується на певних етапах та виборі актуальної теми патріотичного спрямування, події, заходу. Останнім часом усе більшої популярності набуває Всеукраїнський проєкт «З Україною в серці», участь в якому можуть 
взяти учні будь-якої вікової категорії. Мета проєкту: виховувати любов до Батьківщини, викликати у дітей почуття гордості за неї; виховувати повагу до народних символів і сумісної праці; залучати дітей до читання художніх творів про Україну; вчити самостійно знаходити інформацію та вміло представляти іiі аудиторії; ознайомити учнів із державними символами країни, традиціями та звичаями українського народу; удосконалювати навички виразного читання, переказу прочитаних творів.

Форми патріотичного виховання школярів можуть бути досить різноманітними. За кількістю учасників: індивідуальні, парні, групові та масові. За місцем проведення: урочні, позаурочні, позакласні, позашкільні, родинне виховання. За напрямами виховання: естетичні, фізичні, розумові, моральні, трудові, екологічні тощо. Важливу роль також відіграють колективні творчі справи, проєктна діяльність, театралізація, гурткова робота, екскурсії, походи вихідного дня, спортивні змагання, проведення акцій, виставок, українських вечорниць, свят, фольклорних фестивалів, ярмарків тощо [5].

Дієвим методом впливу на формування національно-патріотичних якостей дітей та молоді, за I. Бехом, є рефлексивно-експлічитний [8]. Він передбачає такі етапи: пізнавальний (когнітивний), емоційно-ціннісний (мотиваційний), етап «Я - виклик» (до діi) та вчинково-діяльнісний. Нижче розглянемо ці етапи дещо детальніше.

Пізнавальний етап - індивідуальні зміни і досягнення особистості, які впливають на розвиток навчальної діяльності дитини.

Емоиійно-иіннісний - процес занурення виховання в потаємні душевні глибини учнівської молоді, їх осмислення та перебудова, що здійснюється під наглядом педагога, який активізує рефлексивне мислення учнів та сприяє винесенню його підсумків на зовні, тобто готує їх експлікацію з метою більшого усвідомлення та надання індивідуальної значущості. Завдання цього етапу - віднайти в досвіді учнівської молоді патріотичні вчинки завдяки підсилюванню позитивних емоцій (емоційний виклик, презентування життєвих ситуацій, використання засобів мистецтва).

«Я - виклик» (до діï) - передбачає результати емоційно-ціннісного етапу, готовність до практичних дій.

Вчинково-діяльнісний - це етап створення умов для дій, вчинків, визначення завдань та доручень.

Застосування рефлексивно-імпліцитного методу сприяє посиленню виховної діяльності значної кількості форм та методів становлення патріотизму особистості.

Крім того, у національно-патріотичному вихованні доцільно використовувати й інші ефективні методи: ситуаційно-рольові ігри, «мозкові атаки», аналіз моральних дилем, ситуації успіху, відкриті трибуни, самостійний пошук істини, наративний, кластерний тощо.

Важливо, щоб кожен заклад освіти став для дитини осередком становлення громадянина-патріота України, який готовий брати на себе відповідальність, самовіддано розбудовувати країну як суверенну, незалежну, демократичну, правову, соціальну державу, забезпечувати iіi національну безпеку, сприяти єдності української політичної нації та встановленню громадянського миру й злагоди в суспільстві.

Висновки. Таким чином, патріотичне виховання це суспільна діяльність, що формує ставлення людини до себе, до свого народу й Батьківщини.
Таке ставлення виявляється у відповідних почуттях, переконаннях, ідеях. Отже, патріотизм - це стиль життя.

Національно-патріотичне виховання має бути основою всієї освітньої діяльності, оскільки педагоги та батьки повинні виховати, виростити особистість, яка має почуття гордості за свою державу, сумлінно виконує громадські обов'язки, усвідомлює соціальні потреби Батьківщини та народу, любить оточуючих іiі людей.

Актуальними акцентами національно-патріотичного виховання на сьогодні є такі:

- громадянам України необхідно вчитися жити в повазі один до одного;

- серцевиною сучасного патріотичного виховання має бути вироблення переконаності в дітей і дорослих, що сила українців - у їх єдності;

- єдиними мають бути цінності, спосіб життя та бачення майбутнього розвитку своєї держави.

Школа має стати тим осередком, де плекається духовно багата особистість, формується громадянська зрілість школяра, адже, як стверджує Ш. Амонашвілі: «Школа $\epsilon$ істотою з Майбутнього, і вона вміє спрямовувати дітей тільки в Майбутнє».

\section{СПИСОК ВИКОРИСТАНОЇ ЛІТЕРАТУРИ}

1. Грушевський М. С. На порозі Нової України: гадки і мрії // Твори : у 50 т. / М. С. Грушевський ; редкол. : П. Сохань (голов. ред.), Я. Дашкевич, I. Гирич та ін. - Львів : Видавництво «Світ». - 2007. T. 4. - Кн. 1. - С. 266.

2. Демешкевич В. А. Особливості патріотичного виховання молоді в контексті розвитку сучасного суспільства. URL: www.managment.kr.sch.in.ua/naukovo-praktachna internet-K (дата звернення: 12.01.2020).

3. Киричок В. А. Інноваційні форми і методи патріотичного виховання молодших школярів у позаурочній діяльності. URL: http://www.ukrreferat. com/index.php?referat $=81434 \& p g=0$ (дата звернення: 11.01.2020)

4. Макаренко А. С. Книга для батьків. Про батьківський авторитет / А. С. Макаренко. - Київ : Рад. школа, 1972. - $673 \mathrm{c}$.

5. Матящук В. П. Сучасне патріотичне виховання в школах України / В. П. Матящук. - Тернопіль : Мандрівець, 2014. - 384 с.

6. Мойсеюк Н. Є. Педагогіка : навч. посіб. / Н. Є. Мойсеюк. - Вінниця : Унімерсум-Вінниця, 1998. - 348 c.

7. Радченя I. Реалізація життєвотворчого потенціалу вчителя початкових класів в умовах Нової української школи / I. Радченя // Психолого-педагогічні проблеми сільської школи : збірник наукових праць Уманського державного педагогічного університету імені Павла Тичини. - Умань, 2018. - Вип. 59. C. $272-278$.

8. Рефлексивно-експліцитний метод у формуванні морально стійкої особистості / І. Д. Бех // Теорія і практика управління соціальними системами. -2013.№ 2. - С. 54-60.

9. Соціальна робота в Україні: теорія і практика : науково-методичний журнал. - 2012. - № 2. - С. 58-67.

10. Сухомлинський В. О. Батьківська педагогіка / В. О. Сухомлинський. - Київ : Рад. школа, 1978. $376 \mathrm{c}$.

Дата надходження до редакиії: 21.01.2020 p. 